\title{
Study on the IFNL4 gene ss469415590 variant in Ukrainian population
}

\author{
A. M. Kucherenko", ${ }^{1,2}$ V. M. Pampukha ${ }^{1}$, L. A. Livshits ${ }^{1}$ \\ ${ }^{1}$ Institute of Molecular Biology and Genetics, NAS of Ukraine \\ 150, Akademika Zabolotnoho Str., Kyiv, Ukraine, 03680 \\ ${ }^{2}$ Educational and Scientific Center «Institute of Biology», Taras Shevchenko National University of Kyiv \\ 64/13, Volodymyrska Str., Kyiv, Ukraine, 01601 \\ kucherenko.a.m@gmail.com
}

\begin{abstract}
Aim. To determine genotype and allele disribution for the IFNL4 gene ss 469415590 and examine it for linkage with the IL28B gene rs 12979860 in Ukrainian population. Methods. The studied group consisted of 100 unrelated donors of Eastern European origin representing the population of Ukraine. Genotyping for the IFNL4 gene ss 469415590 was performed using the amplification-refractory mutation system PCR. Genotyping for the IL28B gene rs 12979860 was performed by the PCR-based restriction fragment length polymorphism assay. Results. Genotype frequencies for both studied variants showed no significant deviation from those expected according to Hardy-Weinberg equilibrium. Allelic distribution for ss 469415590 was: TT-0.665, $\Delta G-0.335$. Allelic frequencies of $r s 12979860$ were: $C-0.655, T-0.345$. The results of likelihood ratio test indicated a linkage disequilibrium between the studied variants $(p>0.0001)$, the major alleles ss 469415590 TT and $r 512979860$ C were in phase. The genetic structure of Ukrainian population in terms of two studied polymorphic variants is similar to the European population presented in the "1000 genomes» project. Conclusions. Considering a tight linkage revealed in Ukrainian population between the ss 469415590 variant and rs 12979860 , a crucial genetic marker of chronic hepatitis $C$ treatment efficiency, this polymorphism might be a promising target for further investigation as a pharmacogenetic marker.
\end{abstract}

Key words: ss469415590, rs12979860, IFNL4, linkage disequilibrium.

Introduction. For the past several years wide-range studies have proven the association of the $I L 28 B$ gene rs12979860 with the antiviral therapy efficiency in patients with chronic hepatitis $\mathrm{C}$ (virus genotype 1 ) as well as with the spontaneous viral clearance [1, 2]. However, the exact molecular mechanism for such association remained unclear. According to one of the hypotheses the rs12979860 was expected to be linked to unknown at that moment causal variant [2].

The progress in the field has been achieved recently due to the discovery of previuosly unknown transcript which expression in hepatocytes was activated by hepatitis $\mathrm{C}$ virus exposure [3]. It appeared that a new dinucleotide polymorphic variant ss 469415590 caused a frame-shift mutation creating an open reading frame - the

(C) Institute of Molecular Biology and Genetics, NAS of Ukraine, 2014
IFNL4 (interferon lambda 4) gene [3]. This polymorphism was shown to be in a linkage disequillibrium with rs12979860 in some populations [4] and hence is being extensively studied now as a genetic marker of sustained virological response in chronic hepatitis $\mathrm{C} \mathrm{pa-}$ tients [1-4].

The aim of the study presented was to determine genotype and allele disribution for ss 469415590 and examine it for the linkage with rs12979860 in Ukrainian population.

Matherials and methods. The studied group consisted of 100 unrelated donors of Eastern European origin representing the population of Ukraine. The informed consent was obtained from all participants prior to enrollment in the study. The study has been approved by The Bioethical Committee of Institute of Molecular Biology and Genetics of NAS of Ukraine. 
Table 1

Genotype frequency for studied polymorphic variants

\begin{tabular}{|c|c|c|c|c|c|}
\hline \multirow{2}{*}{ rs 12979860} & \multicolumn{3}{|c|}{ ss469415590 } & \multirow{2}{*}{$\mathrm{D}^{\prime}$} & \multirow{2}{*}{$r^{2}$} \\
\hline & TT/TT & $\mathrm{TT} / \Delta \mathrm{G}$ & $\Delta \mathrm{G} / \Delta \mathrm{G}$ & & \\
\hline $\mathrm{CC}$ & 40 & 0 & 0 & & \\
\hline $\mathrm{CT}$ & 2 & 49 & 0 & 1 & 0.956 \\
\hline TT & 0 & 0 & 9 & & \\
\hline
\end{tabular}

The material of the study was genomic DNA extracted from peripheral blood samples using standard phenol-chloroform technique. Genotyping for the IFNL4 gene ss469415590 was performed using the amplification-refractory mutation system (ARMS) PCR. Additional mismatches were introduced in the primers to avoid the dimer formation.

The primers sequences were IFNL4 $\Delta \mathrm{G}$ : TCC TTT ACA CGG TGA TCG CAG C; IFNL4TT: TCC TTT ACA CGG TGA TCG CAG AA; and IFNL4com: TGA TTG ACC CTG AGC CTG CG. The conditions for amplification were as follows: initial denaturation at $95^{\circ} \mathrm{C}$ for $5 \mathrm{~min}, 30$ cycles of $30 \mathrm{~s}$ at $95^{\circ} \mathrm{C}, 30 \mathrm{~s}$ at $62^{\circ} \mathrm{C}$, and $30 \mathrm{~s}$ at $72{ }^{\circ} \mathrm{C}$, followed by $5 \mathrm{~min}$ final extension at $72^{\circ} \mathrm{C}$. The amplification products of $299 \mathrm{bp}$ were visualized on $2 \%$ agarose gel with ethidium bromide staining. Genotyping for the IL28B gene rs 12979860 was performed by the PCR-based restriction fragment length polymorphism assay as described previously [5].

Statistical analysis has been performed using Gene Pop statistical package [6]. The $\chi^{2}$ test was used to detect deviations from Hardy-Weinberg equilibrium in genotype distribution.

The likelihood-ratio test has been performed to estimate the linkage disequilibrium between ss469415590 and rs12979860. $\mathrm{P}<0.05$ was regarded as a significant value.

Results and discussion. The results of genotyping for both studied polymorphic variants are presented in Table 1. Genotype frequencies for both studied variants showed no significant deviation from those expected according to Hardy-Weinberg equilibrium. The $\chi^{2}$ values for ss469415590 and rs12979860 equaled 0.91 and 0.42 respectively $(d f=2)$. Allelic distribution for ss 469415590 was: $\mathrm{TT}-0.665, \Delta \mathrm{G}-0.335$. Allelic frequencies of rs 12979860 were: $\mathrm{C}-0.655, \mathrm{~T}-0.345$.

The likelihood ratio test was performed to estimate the genotypic linkage disequilibrium between ss 469415590 and rs12979860. The results indicated that the studied
Table 2

Comparative analysis of ss 469415590 and rs 12979860 allele

\begin{tabular}{c|c|c|c}
\hline Population & $\begin{array}{c}\mathrm{ss} 469415590 \\
\mathrm{TT}\end{array}$ & $\begin{array}{c}\mathrm{ss} 469415590 \\
\Delta \mathrm{G}\end{array}$ & $\begin{array}{c}\text { Fisher's exact test results* } \\
\text { (2-tailed p-value) }\end{array}$ \\
\hline $\begin{array}{c}\text { European } \\
\text { Eastern } \\
\text { Asian }\end{array}$ & 0.691 & 0.309 & 0.4759 \\
African & 0.934 & 0.066 & 0.0001 \\
$\begin{array}{c}\text { Ad Mixed } \\
\text { American }\end{array}$ & 0.564 & 0.624 & 0.0001 \\
Ukrainian & 0.665 & 0.335 & 0.0187 \\
\hline \hline $\begin{array}{c}\text { Population } \\
\text { rs } 12979860 \mathrm{C}\end{array}$ & $\mathrm{rs} 12979860 \mathrm{~T}$ & $\begin{array}{c}\text { Fisher's exact test results* } \\
(2-\text { tailed p-value) }\end{array}$ \\
\hline $\begin{array}{c}\text { European } \\
\text { Eastern } \\
\text { Asian }\end{array}$ & 0.682 & 0.318 & 0.4669 \\
African & 0.925 & 0.075 & 0.0001 \\
$\begin{array}{c}\text { Ad Mixed } \\
\text { American }\end{array}$ & 0.558 & 0.442 & 0.0001 \\
Ukrainian & 0.655 & 0.345 & 0.0251 \\
\hline
\end{tabular}

*Calculated between respective population and Ukrainian populations.

variants are tightly linked $(\mathrm{p}>0.0001)$, the alleles ss469415590 TT and rs $12979860 \mathrm{C}$ were in phase.

The recent data show substantial variation in the ss469415590 and rs12979860 allele distributions between different populations.

Therefore, a comparative analysis of the previously reported ss469415590 and rs12979860 variant allele frequencies [7] and the results obtained in this study was performed (Table 2).

There was no difference between the ss 469415590 and rs 12979860 allele distribution reported for European population and that obtained in this study. Respective distributions for both polymorphic variants in Eastern Asian, African, and Ad Mixed American populations were significantly different from the Ukrainian one. 
Conclusions. In this study we have presented the genotype and allele distribution for the recently discovered ss469415590 in the IFNL4 gene in Ukrainian population, obtained using ARMS-PCR. The genetic structure of Ukrainian population in terms of two studied polymorphic variants is similar to the European population presented by the «1000 genomes» project.

Taking into account a tight linkage revealed in Ukrainian population between the ss 469415590 variant and rs12979860, a crucial genetic marker of chronic hepatitis $\mathrm{C}$ treatment efficiency, this polymorphism might be a promising target for further investigation as a pharmacogenetic marker.

Funding. This work was supported by the National Academy of Sciences of Ukraine (grant number 0112U 002108); and the State of Ukraine (grant number 0113 U006253).

Дослідження варіанта ss469415590 гена IFNL4 в популяції України

А. М. Кучеренко, В. М. Пампуха, Л. А. Лівшиць

Резюме

Мета. Встановити розподіл генотипів $і$ алелів за варіантом ss469415590 гена IFNL4, а також дослідити його зчеплення $з$ rs 12979860 у гені IL28B в популяції України. Методи. До групи дослідження входили 100 неспоріднених донорів східно-європейського походження, які представляють популяцию України. Варіант ss 469415590 гена IFNL4 генотипували методом алель-специифічної ПЛР, варіант rs 12979860 гена IL28B - методом ПЛР подальшим аналізом поліморфізму довжини рестрикиійних фрагментів. Результати. Частоти генотипів за обома дослідженими варіантами відповідали очікуваними за рівновагою ХардіВайнберга. Розподіл частот алелей для ss469415590 було наступним: $T T-0,665, \Delta G-0,335$; для rs $12979860-C-0,655, T-0,345$. Результати тесту співвідношення правдоподібності засвідчують нерівновагу за зчепленням між дослідженими поліморфізмами (p > 0.0001), мажорні алелі ss469415590 TT ma rs12979860 C перебувають у фазі. Генетична структура популяиії України за двома дослідженими поліморфними варіантами подібна до європейської популяиії, описаної в проекті «1000 геномів». Висновки. Беручи до уваги тісне зчеплення між варіантом ss469415590 і важливим генетичним маркером ефективності терапії хронічного гепатиту С у популячії України - rs 12979860, ией поліморфізм видається перспективним для подальшого дослідження його як фармакогенетичного маркера.

Ключові слова: ss469415590, rs12979860, IFNL4, нерівновага за зчепленням.

Исследование варианта ss469415590 гена IFNL4 в популяции Украины

А. М. Кучеренко, В. Н. Пампуха, Л. А. Лившиц

Резюме

Цель. Установить распределение генотипов и аллелей по варианmy ss 469415590 гена IFNL4, а также исследовать его сиепление с rs 12979860 в гене IL28B в популящии Украины. Методы. В группу исследования входили 100 неродственных доноров восточно-европейского происхождения, представляющие популящию Украинbl. Вариант ss 469415590 гена IFNL4 генотипировали методом аллель-специфической ПЦР, вариант rs 12979860 гена IL28B - ПЦР с последуюшим анализом полиморфизма длины рестрикиионных фрагментов. Результаты. Частоты генотипов по обоим исследуемым вариантами отвечали ожидаемыми по равновесию Харди-Вайнберга. Распределение частот аллелей для ss469415590 было следуюшим: $T T-0,665, \Delta G-0,335$, для rs 12979860: $C$ 0,655, T-0,345. Результаты теста соотночения правдоподобия указывают на неравновесие по сиеплению между исследуемыми полиморфизмами ( $p>0,0001)$, мажорные аллели ss 469415590 TT u rs 12979860 С находятся в фазе. Генетическая структура популяции Украины по двум исследованным полиморфным вариантам подобна европейской популяции, описанной в проекте «1000 геномов». Выводы. С учетом тесного сиепления между вариантом ss 469415590 и важным генетическим маркером эффективности терапии хронического гепатита $C$ в популяции Украины rs12979860, этот полиморфизм кажется перспективным для дальнейшего исследования его в качестве фармакогенетического маркера.

Ключевые слова: ss469415590, rs12979860, IFNL4, неравновесие по сиеплению.

\section{REFERENCES}

1. Thomas DL, Thio CL, Martin MP, Qi Y, Ge D, O'Huigin C, Kidd $J$, Kidd K, Khakoo SI, Alexander G, Goedert JJ, Kirk GD, Donfield SM, Rosen HR, Tobler LH, Busch MP, McHutchison JG, Goldstein DB, Carrington M. Genetic variation in IL28B and spontaneous clearance of hepatitis C virus. Nature. 2009;461(7265): 798-801.

2. McCarthy JJ, Li JH, Thompson A, Suchindran S, Lao XQ, Patel K, Tillmann HL, Muir AJ, McHutchison JG. Replicated association between an $I L 28 B$ gene variant and a sustained response to pegylated interferon and ribavirin. Gastroenterology. 2010;138 (7):2307-14.

3. Prokunina-Olsson L, Muchmore B, Tang W, Pfeiffer RM, Park H, Dickensheets H, Hergott D, Porter-Gill P, Mumy A, Kohaar I, Chen S, Brand N, Tarway M, Liu L, Sheikh F, Astemborski J, Bonkovsky HL, Edlin BR, Howell CD, Morgan TR, Thomas DL, Rehermann B, Donnelly RP, O'Brien TR. A variant upstream of IFNL3 (IL28B) creating a new interferon gene IFNL4 is associated with impaired clearance of hepatitis C virus. Nat Genet. 2013;45(2):164-71.

4. Booth D, George J. Loss of function of the new interferon $I F N-\lambda 4$ may confer protection from hepatitis C. Nat Genet. 2013;45(2): 119-20.

5. Pampukha VM, Kravchenko SA, Moroz LV, Livshits LA. IFN-入-3 (IL28B) genotyping by restriction fragment length polymorphism method: detection polymorphism of rs12979860. Biopolym Cell. 2011; 27(3):231-4.

6. Rousset $F$. genepop'007: a complete re-implementation of the genepop software for Windows and Linux. Mol Ecol Resour. 2008; 8(1):103-6.

7. 1000 Genomes Project Consortium, Abecasis GR, Auton A, Brooks LD, DePristo MA, Durbin RM, Handsaker RE, Kang HM, Marth $G T$, McVean $G A$. An integrated map of genetic variation from 1,092 human genomes. Nature. 2012;491(7422):56-65.

Received 10.07.14 